\title{
New experiences in nature areas: architecture as a tool to stimulate transformative experiences among visitors in nature areas?
}

Ben Wielenga

\begin{abstract}
Purpose - The purpose of this paper is to share architecture as a tool that is increasingly implemented in nature areas and its potential for stimulating transformative experiences among visitors in nature-based tourism.
\end{abstract}

Design/methodology/approach - Based on three examples of architecture in nature, the value of architecture to nature-based tourism is presented.

Findings - It was found that architecture in nature has a wide range of benefits for nature-based tourism and may form a catalyst for gaining transformative experiences in the examples presented.

Originality/value - The findings presented in this paper touch upon a new way of stimulating transformative experiences among visitors in nature-based tourism by implementing architecture.

Keywords Nature-based tourism, Architecture, Nature areas, Transformational experiences, Visitor management

Paper type Viewpoint

\section{Introduction}

Within the past few years, a shift from the experience economy to transformative experiences has been increasingly noticeable (Seeler and Schänzel, 2019) and global consumerism is gradually being exchanged for personalised travel and obtaining meaningful (Packer and Gill, 2017) and authentic experiences. The potential of transformative travel is widely recognised (Robledo and Batle, 2017) and aims for connecting deeper with the inner self, nature, places and people (Seeler and Schänzel, 2019) through mindful, conscious, immersive, sustainable and/or experiential travel (Seeler and Schänzel, 2019). It is best described as travel with the primary purpose and intention to gather unique, memorable, personal (Pine and Gilmore, 1998), extraordinary (LaSalle and Britton, 2003), multi-sensory (Schmitt, 1999) and emotional (Johnston and Kong, 2011) experiences from consumption that may culminate into long-lasting or structural changes in visitors' skills, attitudes, beliefs, opinions, emotional reactions, behaviour and performances and eventually lead to transformation and self-actualisation. This is achieved through reflection and examination on, and assessing, the experiences gathered.

Until a few years ago, there was wide agreement among scholars that the transformational power of travel remained negligible in academic studies (Wilson et al., 2013). In recent years, however, the attention for the concept gradually increased among scholars and practitioners, which probably is a direct result of changing structures and perspectives
Ben Wielenga is based at the European Tourism Futures Institute (ETFI), NHL Stenden University of Applied Sciences, Leeuwarden, The Netherlands.
Received 24 September 2020 Revised 11 November 2020 Accepted 13 November 2020

(C) Ben Wielenga. Published in Journal of Tourism Futures. Published by Emerald Publishing Limited. This article is published under the Creative Commons Attribution (CC BY 4.0) license. Anyone may reproduce, distribute, translate and create derivative works of this article (for both commercial and non-commercial purposes) subject to full attribution to the original publication and authors. The full terms of this license may be seen at http://creativecommons.org/licences/by/4.0/ legalcode 
among society. In academic contexts, a range of topics is being dealt with recently in connection with experiential travel in different contexts. Firstly, Urquhart (2019) studied the potential role of technology in the future of experiential travel. Secondly, Folmer et al. (2019) explored domestic experiential travel by Chinese millennials, in which motivations and memorable experiences of mountain bikers that biked the Qinghai-Tibet Highway were studied. Finally, Guttentag (2019) described transformative experiences in relation to Airbnb. These three examples show that transformation may occur through different occasions, encounters and/or experiences that take place in different contexts. Nature is one of these contexts.

Especially in nature-based tourism, in which visits mainly take place in national parks, wilderness (Kuenzi and McNeely, 2008) and protected areas (An et al., 2019), the offering of novel, meaningful and transformational experiences may lead to a range of benefits including the attraction of visitors (Weiler et al., 2013), destination satisfaction, loyalty (Wolf et al., 2017), repeat visits and positive word of mouth (Sharpley and Jepson, 2015). Wolf and Wohlfart (2014) add that transformational effects from nature-based activities benefit the psycho-physiological state of individuals, while social advantages include improved family networks, community cohesion, increased social capital (Hewlett and Edwards, 2013) and the conservation of cultures (Wolf et al., 2017). From an economic and environmental perspective, transformational experiences contribute to improving business and investment in nature areas and preservering of local economies (Wolf et al., 2017), changing attitudes towards, and behaviours in, nature, restoration (Winter et al., 2019) and conservation of natural qualities (Moyle et al., 2014; Eagles and McCool, 2002), biodiversity and landscapes (Wolf et al., 2017), stewardship and volunteerism (Winter et al., 2019).

The design and implementation of meaningful and iconic activities and facilities in naturebased tourism are potential contributors to fostering deeper connections with nature and important attributes to enhancing and/or strengthening transformative experiences (Reisinger, 2013). The offering of those are, however, wide and varied (e.g. retreat stays, transformative yoga, graduation trips (Folmer et al., 2019)), and may, depending on the type of activity or facility at hand and how it is embedded in the surroundings, contribute to a lesser or greater extent to transformational experiences. Architecture, a concept that is merely studied in combination with urban contexts, is an example of a tool that is gaining increasing popularity in nature areas for a variety of reasons, but most often, this is because nature organisations find it extremely difficult to balancing between tourism and leisure development in nature on the one hand and persevering natural qualities on the other hand (Wielenga, 2020). Therefore, new ways are sought that keep both aspects in balance. Architecture may have this potential.

Architecture often gives aesthetic meaning to a place (Edwards et al., 2008) and when carefully designed, implemented and adjusted with its surroundings, architecture impacts people's mentality, behaviour, affection, perception (Khaleghimoghaddam and Bala, 2018), identity, ambitions, values (Klingsmann, 2007), feelings (Coburn et al., 2020) and the overall physical health positively. From the point of view of the practical application of architecture in nature-based tourism, the concept is increasingly used to find ways for releasing nature areas for the purpose of tourism and leisure development and, as a result, for stimulating nature awareness and potentially public support among a variety of target groups through the power of attraction of architecture. The latter may form a catalyst for nature protection and conservation to preserve valuable and/or fragile nature for future generations. Moreover, architecture may be used as a tool in zoning management and regulate visitor flows in nature areas (Wielenga, 2020).

The use of architecture in nature and especially nature-based tourism is, however, still poorly studied (Herneoja et al., 2014). By means of three diverse and geographically dispersed examples of architecture in nature areas that were observed by the author, this viewpoint paper combines both concepts and sheds light on the growing trend of 
architecture in nature areas and its potential contribution to transformative experiences in nature-based tourism.

\section{Example 1: Nature concert hall, Sigulda, Latvia}

The Nature Concert Hall is an art object that combines space, light, video and music to experience the beauty of nature (Arch20, 2020). The construction blends with its environment through a combination of natural elements, the geometrical shape of the construction and its volumetric module system (Arch20, 2020). It is a symbiosis of nature, music, science, visual art and poetry. Each year, a specie has been chosen to be the mascot for that year. This specie plays a key role in the development of the event by means of three criteria:

1. location selection;

2. created music that is in accordance with the species' habitat, behaviour and evolution; and

3. interactive workshops to display the species by scientists and researchers (Nature Concert Hall, 2015).

Overall, the object, and the functions that it accommodates, aim for raising awareness of nature and landscape, changing visitor perception on the significance of sustainable development (Nature Concert Hall, 2015), highlighting the surrounding nature (Archdaily, 2021), connecting visitors with their environment and helping to build an understanding of it (Arch20, 2020). On the basis thereof, the Nature Concert Hall pursues to motivate visitors changing their lifestyles and lay the foundation for embracing nature. Internal research showed that organised events motivated almost half of the visitors to undertake concrete attempts in environmental protection (Nature Concert Hall, 2015).

\section{Example 2: National Scenic Routes, Norway}

Norway is traditionally known for its architecture and design that are often adapted to harsh climatic conditions and arduous terrain (Nasjonale Turistveger, 2021). Based upon this knowledge, eighteen highways were appointed by the Norwegian Public Roads Administration as National Scenic Routes as a result of their meaningful sceneries and tourism infrastructure (e.g. rest stops and viewing points) along the road. The routes have been created from the northwest to the southwest, in which natural wonders are displayed and strengthened by art, design and architecture (Visit Norway, 2021) together with accommodation, dining and cultural facilities. As a result, nature can be experienced in new and holistic ways. The overall aim is to increase tourism in the rural areas that are crossed by the highways. In addition, architecture should facilitate visitors in experiencing nature, astonish them and establish a (re)connection with nature. The objects interact with nature, being humble, yet at the same time stand in their own right (Nasjonale Turistveger, 2021) and attract the attention of visitors. Moreover, architectural objects that are placed on the route absorbed the character of that specific part of the route and display the identity of the area. Moreover, it is meant to evoke emotional feelings among visitors and provoke them to come up with suggestive narratives (Nasjonale Turistveger, 2021).

\section{Example 3: Bird Observatory Tij, Haringvliet Delta, The Netherlands}

Bird Observatory Tij has opened in April 2019 and identically represents an egg of the Sandwich Tern, a bird that is representative to the area in which the object is situated. In that sense, the identity of the area is displayed through architecture. The position of 
Tij in the sand, its design, natural patterns, forms, shapes, colours and the natural materials that are used aim to merge the architectural object with its surrounding nature and landscape. The object should be viewed as an extension to nature and landscape, yet stand out to nature and at the same time express humility (Wielenga, 2020). Through the power of architecture, not only a wide combination of target groups is addressed, but also drawn to nature. In that way, these groups come into direct contact with a range of natural, cultural and historical qualities such as delta nature (Vogelbescherming, 2019), a wide variety of bird species (Natuurmonumenten, 2021), different biotopes, vegetation, man-made premises and delta works (Wielenga, 2020). The combination of area qualities that is presented through architecture, aims for increasing nature awareness and astonishment among different target groups, which potentially catalysts into public support and increased funding for the preservation of nature as a result of unique and memorable experiences obtained. From a conservational point of view, the visually appealing power of Tij encourages most visitors to directly stroll towards the object to experience it. Next to that, the use and implementation of natural components (e.g. the construction of architecture surrounded by wetland, specific vegetation and manufactured materials made of natural components) instead of taking hard restrictions by installing fences or gates, prevents visitors to leave the beaten path and leads to a natural zoning system. The attraction of visitors to Tij lead to increased spending in neighbouring facilities and the object is regionally framed by serving as the first touchpoint with and gateway to further explore the delta area.

\section{Conclusion}

The three examples show that architecture is used as a means to achieve a range of objectives in nature-based tourism, on the one hand through a combination of the object(s) functional goal (e.g. interactive nature activities, poetry and music performances aligned with the dynamics of nature) and the design of the interior and exterior such as the Nature Concert Hall and, on the other hand, solely owing to the overall design of the object(s) and its appealing interior and exterior to visitors. Architecture in nature areas is meant to indirectly (re)connect society with nature through its power of attraction, excite people's senses and evoke emotions, feelings of astonishment and appreciation. Overall, the benefits of architecture in nature-based tourism found in this study may be listed as follows:

- representing a nature area's identity by carefully implementing the qualities of the environment into the object;

- functionally displaying and making known a variety of environmental qualities together with, for example, poetry, music, art as disciplines, to offer visitors a holistic, transformational and educational nature experience;

- stimulating rural tourism and increasing human interaction with nature;

- addressing a wide variety of target groups, also outside the scope of nature enthusiasts/lovers and increase their awareness of, astonishment about and appreciation for nature;

- evoking feelings and emotions of visitors to stimulate potential public and financial support for nature conservation, restoration and/or expansion;

- establishing a natural zoning system through architecture's visual appeal and the utilisation of natural materials; and

- serving as a gateway to an area and tempt visitors to further explore. 
The manifold benefits that architecture may have for nature-based tourism are noticeable in the examples presented, as well as the applied resources through which the benefits are obtained. These are something to take into consideration for nature (protection) organisations in the future planning and development of nature areas. The added value of architecture to transformative experiences is a delicate one and something that may become visible in the longer term. However, it can be postulated that architecture's utilisation may lead to transformative experiences among visitors in nature areas, as it is most nature organisations' ultimate goal to establish public support for nature and/or landscape and increase financial funds through memberships and financial contributions as a result of architecture in nature areas. Future research is needed to encounter such effects. Finally, it should not be ignored that the implementation of architectural facilities in nature may be a precarious one, which should be carefully planned, adjusted, executed and monitored at the time the construction of the object is completed to prevent unfavourable effects to nature and landscape by humans. Future research could focus on the long-term effects of architecture on nature and fauna.

\section{References}

An, L.T., Markowski, J., Bartos, M., Rzenca, A. and Namiecinski, P. (2019), "An evaluation of destination attractiveness for nature-based tourism: recommendations for the management of national parks in Vietnam", Nature Conservation, Vol. 32 No. 6, pp. 51-80, doi: 10.3897/ natureconservation.32.30753.

Arch2o (2020), "Nature concert hall pavilion by DJA", available at: www.arch2o.com/nature-concert-hallpavilion-dja/ (accessed 10 September 2020).

Archdaily (2021), "Pavilion and workshops for nature concert hall/DJA", available at: www.archdaily.com/ 537479/pavilion-and-workshops-for-nature-concert-hall-dja (accessed 10 September 2020).

Coburn, A., Vartanian, O., Kenett, Y.N., Nadal, M., Hartung, F., Leichsenring, G.H., Navarrete, G., Mora, J.L.G. and Chatterjee, A. (2020), "Psychological and neural responses to architectural responses", Cortex, Vol. 126, pp. 217-241, doi: 10.1016/j.cortex.2020.01.009.

Eagles, P.F.J. and McCool, S.F. (2002), Tourism in National Parks and Protected Areas, CAB International, Wallingford.

Edwards, D., Griffin, T. and Hayllar, B. (2008), "Urban tourism precincts: an overview of key themes and issues", in Hayllar B, Griffin T. and Edwards D. (Eds), City Spaces - Tourism Places: Urban Tourism Precincts, Elsevier, Oxford, pp. 95-106.

Folmer, A., Tengxiage, A., Kadijk, H. and Wright, A.J. (2019), "Exploring Chinese millennials' experiential and transformative travel: a case study of Mountain bikers in Tibet", Journal of Tourism Futures, Vol. 5 No. 2, pp. 142-156, doi: 10.1108/JTF-02-2019-0018.

Guttentag, D. (2019), "Transformative experiences via airbnb: is it the guests or the host communities that will be transformed?", Journal of Tourism Futures, Vol. 5 No. 2, pp. 179-184, doi: 10.1108/JTF-04-20190038.

Herneoja, A., Mäkinen, M., Rantala, O. and Hakkarainen, M. (2014), "Inscrutable nature-based spatial experience", Annual Architectural Research Symposium, Finland 2014, pp. 196-205.

Hewlett, D. and Edwards, J. (2013), "Beyond prescription: community engagement in the planning and management of national parks as tourist destinations", Tourism Planning \& Development, Vol. 10 No. 1 , pp. 45-63, doi: 10.1080/21568316.2012.723041.

Johnston, R. and Kong, X. (2011), "The customer experience: a road map for improvement", Managing Service Quality: An International Journal, Vol. 21 No. 1, pp. 5-24, doi: 10.1108/ 09604521111100225.

Khaleghimoghaddam, N. and Bala, H.A. (2018), "The impact of environmental and architectural design on users' affective experience", Ybl Journal of Built Environment, Vol. 6 No. 1, pp. 5-19, doi: 10.2478/jbe2018-0001.

Klingsmann, A. (2007), Brandscape, MIT Press, Cambridge, MA. 
Kuenzi, C. and McNeely, J. (2008), "Nature-based tourism", in Renn, O. and Walker, K.D. (Eds), Global Risk Governance, International Risk Governance Council Bookseries, Vol. 1, Springer, Dordrecht, doi: 10.1007/978-1-4020-6799-0_8.

LaSalle, D. and Britton, T.A. (2003), Priceless: Turning Ordinary Products into Extraordinary Experience, Harvard Business School Press, Boston.

Moyle, B.D., Weiler, B. and Moore, S.A. (2014), "Benefits that matter to managers: an exploratory study of three national park management agencies", Managing Leisure, Vol. 19 No. 6, pp. 400-419, doi: 10.1080/ 13606719.2014.910003.

Nasjonale Turistveger (2021), "Architecture and art", available at: www.nasjonaleturistveger.no/en/aboutus/architecture-and-art (accessed 15 September 2020).

Nature Concert Hall (2015), "About", available at: www.natureconcerthall.com/about-us/ (accessed 10 September 2020).

Natuurmonumenten (2021), "Vogelobservatorium tij", available at: www.natuurmonumenten.nl/ natuurgebieden/scheelhoek/vogelkijkpunten/vogelobservatorium-tij (accessed 10 September 2020).

Packer, J. and Gill, C. (2017), "Meaningful vacation experiences", in Filep, S., Laing, J. and Csikszentmihalyi, M. (Eds), Positive Tourism, Routledge, New York, NY, pp. 19-34.

Pine, J.B. and Gilmore, J.H. (1998), "Welcome to the experience economy", Harvard Business Review, Vol. 76 No. 4, pp. 97-105.

Reisinger, Y. (2013), Transformational Tourism: Tourist Perspectives, CABI, Oxfordshire.

Robledo, M.A. and Batle, J. (2017), "Transformational tourism as a hero's journey", Current Issues in Tourism, Vol. 20 No. 16, pp. 1736-1748, doi: 10.1080/13683500.2015.1054270.

Schmitt, B.H. (1999), "Experiential marketing", Journal of Marketing Management, Vol. 15 Nos 1/3, pp. 53-67, doi: 10.1362/026725799784870496.

Seeler, S. and Schänzel, H.A. (2019), "From the fluidity of the experience economy to transformative experiences as a catalyst for positive change: the future of experiential travel", Journal of Tourism Futures, Vol. 5 No. 2, pp. 111-113, doi: 10.1108/JTF-06-2019-081.

Sharpley, R.A.J. and Jepson, D. (2015), "More than sense of place? Exploring the emotional dimension of rural tourism experiences", Journal of Sustainable Tourism, Vol. 23 Nos 8/9, pp. 1-22, doi: 10.1080/ 09669582.2014.953543.

Urquhart, E. (2019), "Technological mediation in the future of experiential tourism", Journal of Tourism Futures, Vol. 5 No. 2, pp. 120-126, doi: 10.1108/JTF-04-2019-0033.

Visit Norway (2021), "Norwegian scenic routes: our most beautiful road trips", available at: www. visitnorway.com/plan-your-trip/travel-tips-a-z/norwegian-scenic-routes/ (accessed 14 September 2020)

Vogelbescherming (2019), "Opening spectaculair vogelobservatorium tij brengt deltanatuur haringvliet dichtbij", available at: www.vogelbescherming.nl/actueel/bericht/opening-spectaculair-vogelobservatorium-tijbrengt-deltanatuur-haringvliet-dichtbij (accessed 10 September 2020).

Weiler, B., Moore, S.A. and Moyle, B. (2013), "Building and sustaining support for national parks in the 21st century: why and how to save the national park experience from extinction", Journal of Park and Recreation Administration, Vol. 31 No. 2, pp. 110-126.

Wielenga, B. (2020), "The bird hide redesigned: merging architecture and nature into build objects in natural environments. A case study towards bird observatory tij in stellendam, Goeree-Overflakkee, and its potential for tourism destination development and management", MSc. Thesis, University of Groningen, the Netherlands, Groningen.

Wilson, G., McIntosh, A.J. and Zahra, A.L. (2013), "Tourism and spirituality: a phenomenological analysis", Annals of Tourism Research, Vol. 42, pp. 150-168, doi: 10.1016/j.annals.2013.01.016.

Winter, P.L., Selin, S., Cerveny, L. and Bricker, K. (2019), "Outdoor recreation, nature-based tourism, and sustainability", Sustainability, Vol. 12 No. 1, pp. 1-12, doi: 10.3390/su12010081.

Wolf, I.D., Ainsworth, G.B. and Crowley, J. (2017), "Transformative travel as a sustainable market niche for protected areas: a new development, marketing and conservation model", Journal of Sustainable Tourism, Vol. 25 No. 11, pp. 1650-1673, doi: 10.1080/09669582.2017.1302454. 
Wolf, I.D. and Wohlfart, T. (2014), "Walking, hiking and running in parks: a multidisciplinary assessment of health and well-being benefits", Landscape and Urban Planning, Vol. 130, pp. 89-103, doi: 10.1016/j. landurbplan.2014.06.006

\section{About the author}

Ben Wielenga is based at the European Tourism Futures Institute (ETFI), affiliated with NHL Stenden University of Applied Sciences in Leeuwarden, The Netherlands. Moreover, Wielenga is a Lecturer in the educational programme of International Tourism Management at NHL Stenden University of Applied Sciences. Ben Wielenga can be contacted at: ben. wielenga@nhlstenden.com

For instructions on how to order reprints of this article, please visit our website: www.emeraldgrouppublishing.com/licensing/reprints.htm

Or contact us for further details: permissions@emeraldinsight.com 